\title{
ВЛИЯНИЕ БИОПРЕПАРАТОВ НА ПРИЖИВАЕМОСТЬ И ПРОДУКТИВНОСТЬ PAСТЕНИЙ IN VITRO
}

Скорейко А., Андрийчук Т., Бильлк Р.

Украинская научно-исследовательская станиия карантина растений Института защчиты растений НААНг. Черновцы, Украина, email: ukrndskr@gmail.com

\begin{abstract}
The results of studies of the influence of biologicals on the process of adaptation of microclonal potato plants to in vivo conditions in greenhouse and field conditions are presented. Treatment of plant material with biological products Planriz and PhytoDoctor promotes the adaptation of in vitro potato plants to in vivo conditions, increases the survival rate of up to $97,8 \%$ of potato seedlings and increases the yield of mini-tubers.
\end{abstract}


Keywords: potatoes, biologicals, microclonal propagation, minibulbs, adaptation

\section{Введение}

Искусственно созданная экосистема для черенков картофеля in vitro приводит к чрезвычайно низкому коэффициенту приживаемости микрорастений в условиях открытого грунта, определяется особым культуральным фенотипом пробирочных растений. Комплекс абиотических факторов in vitro вызывает у микрорастений адаптивные изменения, которые являются целесообразными только в данной специфической среде. Кроме физиологических и анатомических отклонений, которые появляются во время культивирования в асептических условиях, пробирки с растениями практически теряют механизмы устойчивости к фитопатогенам, что затрудняет приживаемость таких растений в открытом грунте $[1,2]$.

Значительную роль в повышении жизнеспособности черенков картофеля при клональном микроразмножении играют эндофитные организмы. Они снабжают растения минеральными и органическими компонентами питания, влияют на развитие растений собственными гормонами, активируют защитную систему противодействия неблагоприятных внешних факторов различной природы. На основе эндофитов отработаны многочисленные препараты. Также доказано, что препараты с участием бактерий родов Klebciella, Pseudomonas, Methylobacterium положительно влияют на развитие черенков картофеля и на приживаемость их в условиях in vivo [3].

Растения, растущие в стерильных условиях на искусственной среде, при пересадке из пробирки в почву подвергаются глубокому стрессу, который продолжается до тех пор, пока указанные системы не придут в норму, то есть пока не закончится их адаптация к новым условиям [4, 5]. Известно, что одним из многочисленных путей решения этой проблемы является изменение гормонального статуса растений in vitro под действием экзогенных регуляторов роста, которые добавляются в питательную среду во время последнего черенкования. Этот прием обеспечивает лучшую приживаемость растений, положительно влияет на их рост и развитие в условиях in vivo. Актуальным является исследование в направлении увеличения адаптивной способности микрорастений к условиям ex vitro, в частности, с использованием биопрепаратов $[2,3,6]$.

Целью наших исследований является изучение влияния биопрепаратов Планриз и ФитоДоктор на приживаемость и продуктивность микрорастений картофеля в тепличных и полевых условиях.

\section{Материалы и методы}

Исследования проводились на базе УкрНИСКР ИЗР (Украинский научноисследовательской станции карантина растений Института защиты растений) в течение 2018-2019 гг. В качестве исходного материала использованы микрорастения картофеля (устойчивые к патогенам), которые выращивали на питательной среде Мурасиге-Скуга в культуральных комнатах при температуре воздуха 22-24 ${ }^{\circ} \mathrm{C}$, относительной влажности 60-70 \%, освещении 4 КЛК, световом периоде 16 часов [7].

Корневую систему микрорастений при пересадке в перлит и почву для адаптации обработано биопрепаратами Планриз и ФитоДоктор. Корни микрорастений в контроле смачивали в дистиллированной воде.

Исследования в тепличных изоляторах проводили на сортах картофеля, различных по спелости (Славянка (среднеспелый), Тирас (ранний), Червона Рута (среднепоздний)). 
Планриз - биологический препарат на основе почвенных бактерий Pseudomonas fluorescens (ТУ 20.15-00717867-006: 2013). Препарат эффективен в качестве профилактического средства против грибных и бактериальных возбудителей болезней, а также оказывает ростостимулирующее действие. Бактерии Pseudomonas fluorescens, кроме прямого подавления вредной микрофлоры, способствуют выделению растениями фитоалексинов, повышают иммунитет, а также во время предпосевной обработки семян подавляют семенную инфекцию.

ФитоДоктор - бактериальный препарат ГП «Энзим» (ТУ У 24.2-32813696 007: 2007 производство «Энзим», г. Ладыжин, Украина). Это порошковый биологический препарат пролонгированного действия для профилактики и лечения сельскохозяйственных растений от комплекса грибных и бактериальных болезней. Основой препарата является живая споровая бактерия Bacillus subtilis, которая продуктами своей жизнедеятельности подавляет размножение многих фитопатогенных грибов и бактерий, а также способствует повышению иммунитета и стимулирует развитие растений.

\section{Результаты и обсуждение}

Во всех вариантах опыта отмечено стимулирующее влияние биопрепаратов на адаптацию и приживаемость микрорастений в тепличных условиях. Выявлено, что наибольшее количество $(87,5$ \% и 92,6 \%) растений прижилось у сортов Славянка и Тирас при замачивании рассады перед высадкой в препарате Планриз, что соответственно в 1,5 и 1,8 раза больше, чем в контроле. Близкие данные получены в варианте, где растения сорта Тирас замачивались в препарате ФитоДоктор приживаемость в 1,6 раза выше, чем в контроле (табл. 1).

Таблица 1. Влияние биопрепаратов на приживаемость растений картофеля in vitro в тепличных условиях (УкрНИСКР ИЗР, 2018-2019 гг.)

\begin{tabular}{|l|l|l|l|}
\hline \multirow{2}{*}{ Варианты опыта } & \multicolumn{3}{|c|}{ Приживаемость растений, \% } \\
\cline { 2 - 4 } & $\begin{array}{l}\text { сорт } \\
\text { Славянка }\end{array}$ & $\begin{array}{l}\text { сорт } \\
\text { Тирас }\end{array}$ & $\begin{array}{l}\text { сорт Червона } \\
\text { Рута }\end{array}$ \\
\hline Контроль (без обработки) & 56,7 & 52,3 & 55,9 \\
\hline $\begin{array}{l}\text { Планриз (бактерии Pseudomonas fluorescens } \\
\text { титр 5,0 х } 10^{9} \text { КОЕ) }\end{array}$ & 87,5 & 92,6 & 71,9 \\
\hline $\begin{array}{l}\text { ФитоДоктор (бактерии Bacillus subtilis титр } \\
\text { 5,0 х } 10^{9} \text { КОЕ) }\end{array}$ & 69,4 & 84,7 & 62,7 \\
\hline НІР05 $^{\text {Кор }}$ & $\mathbf{3 , 5}$ & $\mathbf{4 , 2}$ & $\mathbf{2 , 8}$ \\
\hline
\end{tabular}

В полевых условиях исследовано влияние биологических препаратов ФитоДоктор и Планриз на приживаемость и продуктивность растений картофеля сорта Славянка.

Варианты с замачиванием корней растений в биопрепаратах ФитоДоктор и Планриз показали высокую (89,3 и 97,8 \%) приживаемость растений, соответственно в 1,8 и 2 раза больше, чем в контроле (табл. 2). 
Таблица 2. Влияние биологических препаратов на приживаемость и продуктивность растений картофеля в полевых условиях (УкрНИСКР ИЗР, 2018-2019 гг., сорт Славянка)

\begin{tabular}{|c|c|c|c|c|c|c|c|}
\hline \multirow{4}{*}{$\begin{array}{l}\text { Варианты } \\
\text { опыта }\end{array}$} & \multirow{4}{*}{$\begin{array}{l}\text { Приживае- } \\
\text { мость } \\
\text { растений, } \\
\%\end{array}$} & \multicolumn{4}{|c|}{ Количество миниклубней } & \multicolumn{2}{|c|}{$\begin{array}{l}\text { Ср.масса } \\
\text { миниклуб., } \\
\Gamma \\
\end{array}$} \\
\hline & & $\begin{array}{c}\text { Штук с } \\
\text { растения }\end{array}$ & $\begin{array}{c}\% \text { к } \\
\text { контролю }\end{array}$ & $\begin{array}{c}\text { Штук с } \\
\text { растения }\end{array}$ & $\begin{array}{c}\% \text { к } \\
\text { контролю }\end{array}$ & $\begin{array}{l}10- \\
30\end{array}$ & $\begin{array}{l}30- \\
60\end{array}$ \\
\hline & & \multicolumn{4}{|c|}{ Фракция, мм } & & \\
\hline & & \multicolumn{2}{|c|}{$10-30$} & \multicolumn{2}{|c|}{$30-60$} & & \\
\hline Контроль & 48,5 & 3,3 & - & 1,3 & - & 16,0 & 134,0 \\
\hline $\begin{array}{l}\text { Планриз } \\
\text { (бактерии } \\
\text { Pseudomonas } \\
\text { fluorescens } \\
\text { титр 5,0 х } \\
10^{9} \mathrm{KOE} \text { ) }\end{array}$ & 97,8 & 5,9 & 178,8 & 4,1 & 131,5 & 17,4 & 295,0 \\
\hline $\begin{array}{l}\text { ФитоДоктор } \\
\text { (бактерии } \\
\text { Bacillus } \\
\text { subtilis } \\
5,0 \text { титр } \\
\text { КОЕ) } \\
\end{array}$ & 89,3 & 4,8 & 145,5 & 2,0 & 153,8 & 16,7 & 245,0 \\
\hline $\mathrm{HIP}_{5}$ & 4,7 & - & - & - & - & 0,1 & 10,3 \\
\hline
\end{tabular}

Установлено, что количество миниклубней с одного растения при обработке препаратами по сравнению с контролем возрастала во всех вариантах опыта. Самый высокий показатель количества миниклубней фракций 10-30 и 30-60 мм с одного растения получено при системе обработки препаратом Планриз - соответственно 5,9 и 4,1 шт. с растения. Средняя масса миниклубней с растения увеличивалось на 0,7 г (при обработке препаратом ФитоДоктор) и на 1,4 г (при обработке препаратом Планриз).

\section{Выводы}

Обработка растительного материала биопрепаратами Планриз и ФитоДоктор способствует адаптации пробирочных растений картофеля к условиям in vivo, увеличивая приживаемость рассады картофеля (до 97,8 \%) и среднюю массу миниклубней (на 111-161 г в сравнении с контролем).

\section{Библиография}

1. Бутенко Р. Г. Некоторые физиологические проблемы при культивировании in vitro картофеля. Регуляция роста и развития картофеля. Москва: Наука, 1990. С. 88-98.

2. Подгаєцький А. А., Мацкевич Р. В., Подгаєцький А. Ан. Особливості мікроклонального розмноження видів рослин. Біла Церква: БНАУ, 2018. 209 с.

3. Демчук I. В. Волкова I. В., Пустовойт О. М. Використання біопрепаратів для адаптації мікророслин картоплі до умов in vivo. Сільськогосподарська мікробіологія. 2011. Вип. 14. С. 147-155.

4. Жизнеспособность пробирочных микроклонов картофеля и перспективы повышения их качества. В. Г. Реуцкий и др. / Актуальные проблемы защчиты картофеля, плодовых 
и овощных культур от болезней, вредителей и сорняков: Междунар. научно-практ. конфер., посвященная 100-летию со дня рождения Н.А. Дорожкина (Самохваловичи, 912 авг. 2005 г.). Минск, 2005. С. 27-32.

5. Жизнеспособность растений картофеля in vitro. Анализ проблемы и методика оценки. Реуцкий В. Г. и др. Картофелеводство: Минск, 2007. Т. 12. С. 93-104.

6. Зубкевич О. Н. Использование биологически активных веществ в пробирочной культуре оздоровленных растений картофеля как способ повышения их продуктивности и болезнеустойчивости / Защита растений: Сб. науч. тр. НИРУП "БелИЗР". Минск, 2004. Вып. 28. С. 97-105.

7. Методичні рекомендації. Оздоровлення сортів картоплі методом культури апікальних меристем. Т. М. Олійник та ін. / Ін-т картоплярства НААН. Немішаєве; ТОВ “КВІЦ”, 2012. $28 \mathrm{c}$. 